\title{
Immune Stimulatory and Hepatoprotective Effects of Poly Herbs (Withania somnifera, Liquorice, Allium sativum and Berberis lycium) Mixture Extract in Broilers
}

Noor ul Baseer ${ }^{1}$, Abdul Hafeez ${ }^{1}$, Syed Muhammad Sohail ${ }^{1}$, Muhammad Ijaz ${ }^{1}$, Farman Ullah ${ }^{2,6^{*}}$, Mohammad Salim ${ }^{3}$, Muhammad Altaf Hussain ${ }^{2}$, Momen Khan ${ }^{4}$, Ihsan Ullah Kakar ${ }^{2}$, Sakandar Khan ${ }^{5}$, Mehmood ul Hassan ${ }^{2}$, Sajjad Ahmad $^{2}$ Khalid Khan ${ }^{7}$, Khan Mir Khan ${ }^{8}$ and Imran $\operatorname{Khan}^{9}$

\author{
${ }^{1}$ Faculty of Animal Husbandry and Veterinary Science, University of Agricultural Peshawar KP, Pakistan \\ ${ }^{2}$ Faculty of Veterinary and Animal Sciences, Lasbela University of Agriculture, Water and Marine Sciences, Uthal, Balochistan, Pakistan \\ ${ }^{3}$ Department of Forestry and Wildlife Management, University of Haripur, Khyber Pakhtunkhwa, Pakistan \\ ${ }^{4}$ Livestock and Dairy Development, Khyber Pakhtunkhwa, Pakistan \\ ${ }^{5}$ Department of Parasitology University of Veterinary and Animal Sciences Lahore, Pakistan \\ ${ }^{6}$ Key Laboratory of Agricultural Animal Genetics, Breeding and Reproduction, Education Ministry of China, College of Animal Sciences and \\ Technology, Huazhong Agricultural University, Wuhan 430070, Peoples Republic of China \\ ${ }^{7}$ Department of Economics,Lasbela University of Agriculture, Water and Marine Sciences, Uthal, Balochistan, Pakistan \\ ${ }^{8}$ Faculty of Agriculture, Lasbela University of Agriculture, Water and Marine Sciences, Uthal, Balochistan, Pakistan \\ ${ }^{9}$ Poultry Services Sindh and Baluchistan, Karachi Pakistan
}

DOI: $10.36347 /$ sjavs.2020.v07i06.006

| Received: 12.06 .2020 | Accepted: 20.06.2020 | Published: 30.06 .2020

*Corresponding author: Farman Ullah

Abstract

Original Research Article

This study was aimed to investigate the immunostimulatory and hepatoprotective effects of different levels of herbs extracts like Withania somnifera, Liquorice,Alium sativum and Berberis lycium used to investigate the improvement in immunity and liver function at Agricultural University Peshawar, Pakistan. For this experiment two hundred and forty (240) chicks were randomly assigned in to four major groups A, B, C and D. Each group was further divided in to two sub-groups. Each subgroup was replicated three times carrying 10 chicks per replicate. One of the subgroups was vaccinated against ND (New castle disease), IB (Infectious bronchitis) and IBD (Infectious Bursal disease) according to schedule.Group A was kept as control, while B, C and D were treated with Withania somnifera, Licorice, Alium sativum and Berberis lycium extract at the rate of $(5 \mathrm{gms}+2.5 \mathrm{gms}+2 \mathrm{gms}+8 \mathrm{gms}),(10 \mathrm{gms}+5 \mathrm{gms}+3 \mathrm{gms}+9 \mathrm{gms})$, $(15 \mathrm{gms}+7.5 \mathrm{gms}+4 \mathrm{gms}+10 \mathrm{gms}) \mathrm{gm} / \mathrm{lit}$ of water respectively. AST (Aspartate amino transfarase) and ALT (Alanine amino transfarase)was significantly $(\mathrm{P}<0.05)$ reduced in group $\mathrm{B}$ than rest of the groups, while serum protein and alkaline Phosphatase was significantly $(\mathrm{P}<0.05)$ affected in group $\mathrm{B}$ as compared with other groups. Chicks were reared in cages in an open sided house. The data was recorded for immunostimulant and hepatoprotective effect. ND, IBD and IB was significant $(\mathrm{P}<0.05)$ higher in group B.It is concluded that Withania somnifera, Licorice, Alium sativum and Berberis lycium) extract @ of $(10 \mathrm{gms}+5 \mathrm{gms}+3 \mathrm{gms}+9 \mathrm{gms}) \mathrm{gm} / \mathrm{L}$ of water could be effectively utilized to improve immunity and liver function.

Keywords: Immunostimulant, liver function, Alanine aminotransferase, Aspartate aminotransferase, serum protein, alkaline phosphatase, Herbs.

Copyright @ 2020: This is an open-access article distributed under the terms of the Creative Commons Attribution license which permits unrestricted use, distribution, and reproduction in any medium for non-commercial use (NonCommercial, or CC-BY-NC) provided the original author and source are credited.

\section{INTRODUCTION}

Scientific interest in medicinal plants has developed rapidly due to increased evidences regarding the therapeutic efficacies of plant-derived drugs against different ailments. The research on medicinal plants has also gained momentum because these have been reported for least or no associated side effects unlike most of the commonly available drugs of synthetic origin. Based on current research and financial investments into medical plants, it seems that they will continue to play important role in human health. The medicinal plants find its application in pharmaceutical, cosmetic, agricultural and food industry. The use of medicinal herbs for curing disease has been documented in history of all civilizations [1]

In this regard, roots of Berberis lycium has been reported as antihypertensive, intropic and antiarrhythmic agent which make it potential candidate for use in cardio vascular disorders [2]. In broiler chicks, it has also been for immunomodolatory, 
hypolipidemic and growth promoting activities [3]. Berberis roots are used as folk remedy worldwide for the treatment of various inflammatory ailments including lumbago, rheumatism and to reduce fever [4]. Leaves are given in jaundice. Berberis Lycium contains a well-known alkaloid "berberine" which has marked antibacterial effects. Extract of the Berberis lycium fruit shows antihistaminic and anticholenergic activities, while Berberis vulgaris possesses stomachic, astringent, and anti-inflammatory effects [4].

Alium sativum is used to treat acne and there is also some evidence that it can assist in managing high cholesterol levels [5]. Garlic has an international reputation for lowering the blood pressure, blood cholesterol levels and generally improving the health of the cardio-vascular system. It has immuonomodulatory activities [6]. Epidemiological and animal experimental studies have shown that garlic consumption reduces the incidence of cancer of stomach, colon, breast and cervix [7]. Risk factors for cardiovascular disease, including high cholesterol, high homocysteine, hypertension and inflammation, increase the risk of dementia, including its most common form; Alzheimer's disease (AD) can be controlledby the usage of garlic [8]. Inhibition of cholesterol, LDL oxidation, and platelet aggregation by Aged Garlic Extract (AGE), inhibits arterial plaque formation. AGE decreases homocysteine, lowers blood pressure, and increases microcirculation, which is important in diabetes, where microvascular changes increase heart disease and dementia risks [8]. The majority of garlic $(65 \%)$ is water, and the bulk of the dry weight is composed of fructose-containing carbohydrates, followed by sulfur compounds, protein, fiber, and free amino acids (1). It also contains high levels of saponins, phosphorus, potassium, sulfur, zinc, moderate levels of selenium and Vitamins A and C, and low levels of calcium, magnesium, sodium, iron, manganese, and B-complex vitamins; garlic also has a high phenolic content (2). A majority of the compounds present in garlic are water-soluble (97\%) with small amounts of oil-soluble compounds also present $(0.15-0.7 \%)$.

Liquorice, is one of the biologically most active herbs and is famous for anti-inflammatory activities [9]. Immunological adjuvant effect of Glycyrrhiza uralensis saponins on the immune responses, [10, 11]. Liquorice contains a number of active ingredients. Glycyrrhizin possesses antiinflammatory, antiulcer, expectorant, antimicrobial and anxiolytic like activities [9].

Withania somnifera is a well-recognized registered drug mentioned in most pharmacopoeias. It has also anti-inflammatory and hemato/ immunomodulator activities [12]. The use of W. somnifera has been mainly associated to its modulatory effect on the immune system Das and Panda [13]. Preparations obtained from this plant have been shown to enhance antibodies titer, increase the activity of lysosomal enzymes and increase phagocytosis by macrophages [12]. Administration of aqueous extract of fruits of Withania somnifera significantly lowered the blood sugar, serum cholesterol, serum LPO, and hepatic LPO levels [14]. Keeping in view the diverse biological and pharmacological activities of poly herbs (Withaniasomnifera, Liquorice, Allium sativum and BerberisLycium) this study has been designed to evaluate the immunostimulatory and hepatoprotective effects.

\section{MATERIALS AND METHODS}

This research study was conducted to investigate the effect of different levels of poly-herbal extract (Withaniasomnifera, Liquorice, Allium sativum and Berberis Lycium) in broiler chicks. The study was conducted at Experimental poultry Farm of University of Agriculture, Peshawar, Khyber Pakhtonkhwa.

\section{Experimental Design}

The experiment was conducted in Completely Randomized Block Design (CRBD) with two factors that is (i) treatment with different level of plant materials (ii) vaccines. For the purpose, two hundred forty (240) day-old-broiler chicks of approximately the same weight and appearance were purchased from the local market. These chicks were divided into four treatment groups A, B, C and D, respectively. These groups were divided into two sub-groups for the different treatments. Each group carried three replicate (10 chicks/ replicate). Treatment group designated as A was kept as control, while B, C and D were treated with an aqueous extract mixture of Withaniasomnifera, Liquorice, Garlic and Berberis Lyciumat the rate of $(5 \mathrm{gms}+2.5 \mathrm{gms}+2 \mathrm{gms}+8 \mathrm{gms}),(10 \mathrm{gms}+5 \mathrm{gms}+$ $3 \mathrm{gms}+9 \mathrm{gms}),(15 \mathrm{gms}+7.5 \mathrm{gms}+4 \mathrm{gms}+10 \mathrm{gms})$ per liter of drinking water to each group, respectively. Chicks were reared in an open sided house in pens. Feeder, drinker, bulb and other necessary materials were provided to chicks in each pen to maintain sound managemental and environmental conditions. Experiment was lasted for 35 days.

\section{Preparation of Mixture of Plants}

Withaniasomnifera, Liquorice, Allium sativum and Berberis lycium powder were obtained from Khyber Bazar Peshawar.The plant parts (fruit, leaves, and root) were cut into small pieces, air dried and powdered followed by storage in screw capped bottles at $4{ }^{\circ} \mathrm{C}$ till use in the experiment.

\section{Research study parameters}

Data was recorded for Antibody titer determination by heamagglutination inhibition (HI) test to determine its titer against Newcastle disease (ND) and Infectious Bronchitis disease (IB), as described by Alexander and Chettle [15] and also performed ELISA to measure its antibody level against infectious bursal disease (IBD) as described by Marquardt et al. [16]. The hepatoprotective parameters including ALT 
(Alanine aminotransferase), AST (Aspartate aminotransferase), serum protein, ALP (alkaline phosphatase) were determined by using Randox test kits.

\section{STATISTICAL ANALYSIS}

The data were statistically analyzed by the standard procedure of Analysis of Variance using two factorial completely randomized block design (RCBD) as described by Steel and Torrie [17]. The statistical computer package [18] was used to perform the above analysis.

\section{RESULTS AND DISCUSION}

Quantification of Antibody Titers to ND and IB Vaccines

\section{HI Antibody Titer against ND}

The mean HI antibody titers against ND vaccine were 2.26, 5.71, 2.50 and 2.68 for groups A, B, $\mathrm{C}$ and D, respectively. For subgroups vaccinated and non-vaccinated it was 3.54 and 3.04, respectively (Table 1).

Table-1: Titres of ND, IB and IBD (mean values) in broiler chicks fed different levels of (Withania somnifera, Liquorice, Allium sativum and Berberis lycium).

\begin{tabular}{|l|l|l|l|}
\hline \multirow{2}{*}{ Group } & Mean & Mean & Mean \\
\cline { 2 - 4 } & ND & IB & IBD \\
\hline $\mathrm{A}$ & $2.26^{\mathrm{b}}$ & $3.15^{\mathrm{b}}$ & $983.33^{\mathrm{b}}$ \\
\hline $\mathrm{B}$ & $5.71^{\mathrm{a}}$ & $6.13^{\mathrm{a}}$ & $1591.67^{\mathrm{a}}$ \\
\hline $\mathrm{C}$ & $2.50^{\mathrm{b}}$ & $2.91^{\mathrm{b}}$ & $983.33^{\mathrm{b}}$ \\
\hline $\mathrm{D}$ & $2.68^{\mathrm{b}}$ & $2.96^{\mathrm{b}}$ & $1093.33^{\mathrm{b}}$ \\
\hline Vaccination & & & \\
\hline Vac & $3.54^{\mathrm{a}}$ & 3.69 & $1162.50^{\mathrm{a}}$ \\
\hline Non-vac & $3.04^{\mathrm{ab}}$ & 3.89 & $1163.33^{\mathrm{ab}}$ \\
\hline Interaction & & & \\
\hline $\mathrm{A} \times$ Vac & 2.53 & 3.00 & 983.33 \\
\hline $\mathrm{A} \times$ Non-Vac & 2.00 & 3.30 & 983.33 \\
\hline $\mathrm{B} \times$ Vac & 5.90 & 5.86 & 1600.00 \\
\hline $\mathrm{B} \times$ Non-Vac & 5.53 & 6.40 & 1583.33 \\
\hline $\mathrm{C} \times$ Vac & 2.56 & 2.80 & 1033.33 \\
\hline $\mathrm{C} \times$ Non-Vac & 2.43 & 3.03 & 933.33 \\
\hline $\mathrm{D} \times$ Vac & 3.16 & 3.10 & 1033.33 \\
\hline $\mathrm{D} \times$ Non-Vac & 2.20 & 2.83 & 1153.33 \\
\hline
\end{tabular}

abc: Means within the same row having different superscripts are significantly different $(\mathrm{P}<0.05)$.

Mean antibody titer against ND was significantly $(\mathrm{P}<0.05)$ higher in-group $\mathrm{B}$ among the treatments and between the vaccinated and nonvaccinated. Non-significant $(\mathrm{P}>0.05)$ antibody titers were recorded among the group interaction, though the significant differences exist, the antibody titers value were below the protected level (5.00). The finding of present study are consistent with those reported by Dorhi et al. [11], who used the standardized ethanol extracts of Allium sativum (garlic), Glycyrrhizaglabra (liquorice), Plantago major (plantain) and
Hippophaerhamnoides (sea buckthorn) in laying hens for their effects on cellular immunity and reported that herbal extracts enhanced specific cell immunity with improved ability of the host to resist against invading pathogens. Findings of our research study are also in line with the findings of Jinag et al. [19] and Valle et al. [20], who reported that serum antibody titer against New Castle disease was increased by feeding Aloe Vera. Contrarily, our study is not in agreement to the findings of Mushtaq and Durrani [21], who reported that, there is no influence $(\mathrm{P}<0.05)$ on antibody titer against ND while feeding Withania somnifera to the broiler chicks.

\section{HI Antibody Titer against IB}

Mean antibody titer against IB for group A, B, $\mathrm{C}$ and D were 3.15, 6.13, 2.91 and 2.96 while subgroups of vaccinated and non-vaccinated it was 3.69 and 3.89, respectively (Table 1 ). It was observed that mean antibody titer against IB was significantly $(\mathrm{P}<0.05)$ effective in-group B among the treated. No significant difference $(\mathrm{P}>0.05)$ was found between the vaccinated and non-vaccinated groups and also among the interaction of vaccinated and non-vaccinated groups. The antibody titer of groups was recorded with in the range of normal protected value of IB. These results are in agreement with the findings of Dorhi et al. [21], who used the standardized ethanol extracts of Allium sativum (garlic), Glycyrrhizaglabra (liquorice), Plantago major (plantain) and Hippophaerhamnoides (sea buckthorn) in laying hens for their effects on cellular immunity and reported that herbal extracts definitely enhanced specific cell immunity and may therefore improve host resistance. The results of present research disagreed with the findings of Sajjad and Durrani [22] who fed different levels of P.anisum extract and found no significant difference among the treatment and control groups against IB. Our study findings are in agreement with the findings of Mushtaq and Durrani [23], who reported that there is significant $(\mathrm{P}<0.05)$ effect on antibody titer against IB while feeding Withania somnifera to the broiler chicks.

\section{ELISA based Antibody Titer against IBD}

Mean ELISA antibody titers against IBD for groups A, B, C and D were 983.33, 1591.67, 983.33 and 1093.33 and those for vaccinated and nonvaccinated groups were 1162.50 and 1163.33, respectively (Table 1). Mean antibody titer against IBD was highly significant $(\mathrm{P}<0.05)$ in-group $\mathrm{B}$ among the treated and also significant $(\mathrm{P}<0.05)$ between the vaccinated and non-vaccinated groups, while nonsignificant $(\mathrm{P}>0.05)$ among the group interaction. The antibody titer for IBD in group B was above and within the protected level. Our findings can be compared with the research findings of Wheeler et al. [24], who reported that herbal drugs had anti stress and immunomodulatry property in chicken. The findings also supported by the finding of Dorhi et al. [11], who used the Standardized ethanol extracts of Allium 
sativum (garlic), Glycyrrhizaglabra (liquorice), Plantago major (plantain) and Hippophaerhamnoides (sea buckthorn) for their effects on cellular immunity in laying hens and reported that herbal extracts definitely enhanced specific cell immunity and may therefore improve host resistance. The result can also be justified by the findings of Sajjad and Durrani [22], who reported that medicinal herb extract, given in drinking water had significant effect $(\mathrm{P}<0.05)$ on the mean antibody titer against IBD of broiler chicks. Our study is in line with the findings of Mushtaq and Durrani [21], who reported that there is significant $(\mathrm{P}<0.05)$ increase in antibody titer against IBD while feeding Withaniasomnifera to the broiler chicks.

\section{LIVER FUNCTION TESTS (LFTS)}

\section{AST (Aspartate aminotransferase)}

Average serum AST value per chick at the end of experiment was 32.66, 18.81, 29.83 and $30.10 \mathrm{U} / \mathrm{L}$ for group A, B, C and D, respectively, (Table 2).
Average values of vaccinated and non-vaccinated were 26.78 and $28.92 \mathrm{U} / \mathrm{L}$, respectively. The AST data revealed significant $(\mathrm{P}<0.05)$ difference among the groups and significant difference between the vaccinated and non-vaccinated subgroups. Similarly, no significant $(\mathrm{P}>0.05)$ difference was found among the interaction of vaccinated and non-vaccinated with groups. Significant differences existed in the treated groups. AST was significantly $(\mathrm{P}<0.05)$ reduced in group B as compared to other groups. Our study is in line with the findings of Mushtaq and Durrani [21], who reported that there is significant $(\mathrm{P}<0.05)$ control on AST while feeding Withaniasomnifera to the broiler chicks.

\section{ALT (Alanine amino transferase)}

Average ALT value per chick at the end of experiment was $31.68,19.78,30.25$ and $29.78 \mathrm{U} / \mathrm{L}$ for group A, B, C and D, respectively (Table 2).

Table-2: Mean AST ALT Serum protein and ALP levels in broiler chicks fed different levels of (Withania somnifera, Liquorice, Allium sativum and Berberis lycium).

\begin{tabular}{|l|l|l|l|l|}
\hline \multirow{2}{*}{ Group } & Mean & Mean & Mean & Mean \\
\cline { 2 - 5 } & AST & ALT & Serum protein & ALP \\
\hline A & $32.66^{\mathrm{a}}$ & $31.68^{\mathrm{a}}$ & $7.50^{\mathrm{ba}}$ & $30.53^{\mathrm{a}}$ \\
\hline $\mathrm{B}$ & $18.81^{\mathrm{c}}$ & $19.78^{\mathrm{c}}$ & $7.38^{\mathrm{b}}$ & $20.31^{\mathrm{b}}$ \\
\hline $\mathrm{C}$ & $29.83^{\mathrm{b}}$ & $30.25^{\mathrm{ba}}$ & $7.80^{\mathrm{a}}$ & $29.80^{\mathrm{a}}$ \\
\hline $\mathrm{D}$ & $30.10^{\mathrm{ba}}$ & $29.78^{\mathrm{b}}$ & $7.00^{\mathrm{c}}$ & $30.11^{\mathrm{a}}$ \\
\hline Vaccination \\
\hline Vac & $26.78^{\mathrm{b}}$ & $27.20^{\mathrm{ab}}$ & 7.44 & 27.67 \\
\hline Non-vac & $28.92^{\mathrm{a}}$ & $28.54^{\mathrm{a}}$ & 7.40 & 27.70 \\
\hline Interaction & 31.36 & 30.46 & 7.60 & 31.46 \\
\hline A $\times$ Vac & 31.36 & 29.60 \\
\hline $\mathrm{A} \times$ Non-Vac & 33.96 & 32.90 & 7.40 & 20.53 \\
\hline $\mathrm{B} \times$ Vac & 18.60 & 19.96 & 7.06 & 20.10 \\
\hline $\mathrm{B} \times$ Non-Vac & 19.03 & 19.60 & 7.70 & 29.43 \\
\hline $\mathrm{C} \times$ Vac & 28.30 & 29.33 & 7.63 & 30.16 \\
\hline $\mathrm{C} \times$ Non-Vac & 31.36 & 31.16 & 7.96 & 29.26 \\
\hline $\mathrm{D} \times$ Vac & 28.86 & 29.06 & 7.46 & 30.96 \\
\hline $\mathrm{D} \times$ Non-Vac & 31.33 & 30.50 & 6.53 & \\
\hline
\end{tabular}

abc: Means within the same row having different superscripts are significantly different $(\mathrm{P}<0.05)$.

Average values of vaccinated and nonvaccinated were 27.20 and 28.54 respectively. Significant $(\mathrm{P}<0.05)$ difference was observed in the mean ALT levels among the treatments and between the vaccinated and non-vaccinated and no significant ( $\mathrm{P}>0.05)$ difference was found among the interaction of vaccinated and non-vaccinated. However, group B was observed with the lowest numerical value of $19.78 \mathrm{iu} / \mathrm{ml}$. Our study in line to the findings of Mushtaq and Durrani [21], who reported that there is significantly $(\mathrm{P}<0.05)$ control on ALT while feeding Withaniasomnifera to the broiler chicks.

\section{Serum Protein}

Average serum protein value per chick at the end of experiment was 7.50, 7.38, 7.80 and $7.00 \mathrm{mg} / \mathrm{dl}$ for group A, B, C and D, respectively (Table 2).
Average values of vaccinated and non-vaccinated were 7.44 and $7.40 \mathrm{mg} / \mathrm{dl}$, respectively. Significant $(\mathrm{P}<0.05)$ difference was observed on the mean serum protein levels among the treated and between the vaccinated and non-vaccinated and also among the interaction of vaccinated and non-vaccinated. The result of the present study showed that group D had significantly lower serum protein as compared to the others groups. Our study in line with the findings of Mushtaq and Durrani [21], who reported that there is significantly $(\mathrm{P}<0.05)$ control on serum protein while feeding Withania somnifera to the broiler chicks.

\section{ALP (alkaline phosphatase)}

Average serum ALP values were found to be 30.53, 20.31, 29.80 and 30.11 U/L for group A, B, C and $\mathrm{D}$, respectively (Table 2). Average values of 
vaccinated and non-vaccinated groups were 27.67 and 27.70, respectively. The ALP data revealed significant $(\mathrm{P}<0.05)$ difference among the groups and no significant $(\mathrm{P}>0.05)$ differencewas found among the vaccinated and non-vaccinated and interaction of vaccinated and non-vaccinated groups. Significantly reduced ALP was observed in group B as compared to the other groups. Our study in line with the findings of Mushtaq and Durrani [21], who reported that there is significantly $(\mathrm{P}<0.05)$ control over ALP, while feeding Withania somnifera to broiler chicks.

In conclusion, findings of this study showed that a poly-herbal mixture containing $W$. somnifera, Liquorice, A. sativum and B.Lycium extract is a potential candidate to improve immunity and liver functionin poultry production.

\section{REFERENCES}

1. Limenih $\mathrm{Y}$, Umer $\mathrm{S}$, Wolde-Mariam $\mathrm{M}$. Ethnobotanical study on traditional medicinal plants in Dega Damot woreda, Amhara region, North Ethiopia. Int J Res Pharm Chem. 2015;5(2):258-73.

2. Abidi P, Chen W, Kraemer FB, Li H, Liu J. The medicinal plant goldenseal is a natural LDL-lowering agent with multiple bioactive components and new action mechanisms. Journal of lipid research. 2006 Oct 1;47(10):2134-47.

3. Niazi M, Durrani FR. Investigated the effect of aqueous extract of Berberius lycium on the immunity, lipid profile, and overall performance of broiler chicks. M. Sc (Hons) Thesis, Agric. Univ. Peshawar, Pakistan. 2006.

4. Yeşilada E, Küpeli E. Berberis crataegina DC. root exhibits potent anti-inflammatory, analgesic and febrifuge effects in mice and rats. Journal of ethnopharmacology. 2002 Feb 1;79(2):237-48.

5. Qureshi AA, Din ZZ, Abuirmeileh N, Burger WC, Ahmad Y, Elson CE. Suppression of avian hepatic lipid metabolism by solvent extracts of garlic: impact on serum lipids. The Journal of nutrition. 1983 Sep 1;113(9):1746-55.

6. Truchliński J, Krauze M, Cendrowska-Pinkosz M, Modzelewska-Banachiewicz B. Influence of garlic, synthetic 1, 2, 4-triasole derivative and herbal preparation echinovit $\mathrm{C}$ on selected indices of turkeyhens non-specific immunity. Polish journal of veterinary sciences. 2006;9(1):51-5.

7. SU CC, CHEN GW, TAN TW, LIN JG, Chung JG. Crude extract of garlic induced caspase-3 gene expression leading to apoptosis in human colon cancer cells. in vivo. 2006 Jan 1;20(1):85-90.

8. Borek C. Garlic reduces dementia and heart-disease risk. The Journal of nutrition. 2006 Mar 1;136(3):810S-2S.

9. Aly AM, Al-Alousi L, Salem HA. Licorice: a possible anti-inflammatory and anti-ulcer drug. Aaps Pharmscitech. 2005 Mar 1;6(1):E74-82.

10. Sun HX, Pan HJ. Immunological adjuvant effect of Glycyrrhiza uralensis saponins on the immune responses to ovalbumin in mice. Vaccine. 2006 Mar 10;24(11):1914-20.

11. Dorhoi A, Dobrean V, Zăhan M, Virag P. Modulatory effects of several herbal extracts on avian peripheral blood cell immune responses. Phytotherapy Research: An International Journal Devoted to Pharmacological and Toxicological Evaluation of Natural Product Derivatives. 2006 May;20(5):352-8.

12. Ziauddin M, Phansalkar N, Patki P, Diwanay S, Patwardhan B. Studies on the immunomodulatory effects of Ashwagandha. Journal of ethnopharmacology. 1996 Feb 1;50(2):69-76.

13. DAS N, PANDA D, PANDA R. Synergistic effect of herbal immunostimulant" IMMU-21 and anticoccidial-1HP-250C and ACC-7 against induced Eimeria tenella infection in broiler chicks. Phytomedica. 2001;2:77-84.

14. Hemalatha S, Wahi AK, Singh PN, Chansouria JP. Hypoglycemic activity of Withania coagulans Dunal in streptozotocin induced diabetic rats. Journal of Ethnopharmacology. 2004 Aug 1;93(2-3):261-4.

15. Alexander DJ, Chettle NJ. Procedures for the haemagglutination and the haemagglutination inhibition tests for avian infectious bronchitis virus. Avian Pathology. 1977 Jan 1;6(1):9-17.

16. Voller A. Enzyme-linked immunosorbent assay. Manual of clinical immunology. 1980:359-71.

17. Steel RGD and Torrie JH. Principles and procedures of statistics: A biometrical approach. $2^{\text {nd }}$. Ed. McGraw-Hill, Singapore; 1981.

18. Heylen W, Lammens S, Sas P. Modal analysis theory and testing. Leuven: Katholieke Universiteit Leuven; 1997.

19. Lin J, Zhang FY, Xu Y, Ting ZX, Po YD. Effects of gel, polysaccharide and acemannan from Aloe vera on broiler gut flora, microvilli density, immune function and growth performance. Chinese J. Vet. Sci. 2005;25(6):668-71.

20. Anunciado RV, Valle-Paraso MG, Vidamo PJ, Lapitan AM. Effects of Aloe Vera (Aloe barbadensis) on the White Blood Cell Count and Antibody Titer of Broiler Chickens Vaccinated Against Newcastle Disease. Philippine Journal of Veterinary Medicine. 2005;42(1):1-.

21. Khan M, Durrani F. Hematological hypolipidemic hypoglycemic anticoccidial hepatoprotective immunostimulant and growth promotant effect of Withania somnifera in broiler production (Doctoral dissertation, MS Thesis. KPK Agric Univ., Peshawar, Pakistan).

22. Sajjad A. Aniseed extract as immune stimulant and growth promoter in broiler chicks (Doctoral dissertation, MSc Thesis, NWFP Agric Univ, Peshawar).

23. Chand N, Durrani FR, Qureshi MS, Durrani Z. Role of Berberis lycium in reducing serum cholesterol in broilers. Asian-australasian journal of animal sciences. 2007 Jan 24;20(4):563-8.

24. Wheeler RD. U.S. Patent No. 5,332,156. Washington, DC: U.S. Patent and Trademark Office; 1994. 